\title{
Phytosociological contrast of ferns and lycophytes from forest fragments with different surroundings matrices in southern Brazil
}

\author{
V. L. Silva ${ }^{a, b *}$, I. T. Mallmann ${ }^{a}$, V. Graeff ${ }^{a}$, J. L. Schmitt ${ }^{a}$ and K. Mehltreter ${ }^{b}$ \\ a'Laboratório de Botânica, Universidade Feevale, ERS-239, 2755, CEP 93525-075, Novo Hamburgo, RS, Brasil \\ 'Instituto de Ecología, A.C., Red de Ecología Funcional, Carretera antigua a Coatepec-351, 91070 Xalapa, \\ Veracruz, México \\ *e-mail: suicinivleao@gmail.com
}

Received: October 2, 2017 - Accepted: November 27, 2017 - Distributed: August 31, 2019

(With 2 figures)

\begin{abstract}
Forest edges typically exhibit higher luminosity and lower humidity than the forest interior, resulting in an abiotic gradient. However, the degree of abiotic difference can be affected from the type of the matrix, influencing the selection of species. We compared the floristic and phytosociological structure of understory communities of ferns and lycophytes of the edge and interior of three forest sites influenced by different types of surrounding matrices (natural field, Pinus plantation, and cultivation of crops). In the region of Araucaria Forest, in Rio Grande do Sul, Brazil, twelve $10 \times 10$ $\mathrm{m}$ plots were selected at the edge and interior of each site, totaling 72 plots and to evaluate the phytosociological contrast, using as a parameter coverage and species richness per plot to evaluate this contrast. We recorded a total of 38 species in the studied areas, distributed in 15 families. The results show that the edge effect acts at different intensities in the analyzed sites. In the site with unnatural matrix, the composition was more homogeneous both in the edges and in the interiors and presented lower richness, showing a more pronounced and deep impact. Already in the site with natural matrix surroundings, although the border also presents low richness, the interior was about $3 \mathrm{x}$ richer. Based on our results, we concluded that fern conservation efforts should focus on fragments of Araucaria Forest inserted in the natural field, because the conversion of natural field into Pinus planting and cultivation of crops decreases ferns species both in the edges and forest interiors of the studied fragments, besides altering the phytosociological structure leading the communities to simplification.
\end{abstract}

Keywords: araucaria forest, community structure, edge effects, fragmentation, pteridophytes, richness.

\section{Contraste fitossociológico de samambaias e licófitas de fragmentos florestais com diferentes matrizes de entorno no sul do Brasil}

\section{Resumo}

Bordas florestais tipicamente exibem maior luminosidade e menor umidade que o interior florestal, resultando em um gradiente abiótico. Entretanto, o grau de diferença abiótica pode ser afetado a partir do tipo da matriz, influenciando a seleção de espécies. Comparamos a composição florística e a estrutura fitossociológica das comunidades de samambaias e licófitas na borda e interior de três sítios influenciados por diferentes matrizes (campo natural, plantio de Pinus e cultivo de olerícolas). Na região de Floresta com Araucária no Rio Grande do Sul, Brasil, foram sorteadas doze parcelas de $10 \times 10 \mathrm{~m}$ na borda e no interior de cada sítio, totalizando 72 parcelas para avaliar o contraste fitossociológico, utilizando como parâmetro cobertura e riqueza das espécies por parcela para avaliar esse contraste. Registramos um total de 38 espécies nas áreas estudadas, distribuídas em 15 famílias. Os resultados mostraram que o efeito de borda atua em intensidades distintas nos sítios analisados. Nos sítios com matriz antropizada, a composição foi mais homogênea tanto nas bordas, quanto nos interiores e apresentou menor riqueza, demonstrando impacto mais pronunciado e profundo. Já no sítio com matriz de entorno natural, apesar da borda também apresentar baixa riqueza, o interior foi cerca de 3x mais rico. Sugerimos que os esforços de conservação de samambaias e licófitas em fragmentos com araucária, devem se concentrar em sítios inseridos em campo natural, pois, a conversão destes em plantio de Pinus e cultivo de olerícolas, diminui a diversidade dessas plantas, tanto nas bordas quanto nos interiores da floresta, além de alterar a estrutura fitossociológica levando as comunidades à simplificação.

Palavras-chave: floresta com araucária, estrutura comunitária, efeito de borda, fragmentação, pteridófitas, riqueza. 


\section{Introduction}

One of the major threats to biodiversity in forests is fragmentation by anthropogenic origin (Laurance and Bierregaard, 1997). Besides being rapidly destroyed, the forests that once occupied large areas, are now divided in small patches often surrounded by non-original matrices (Harper et al., 2005). Haddad et al. (2015) revealed that approximately $20 \%$ of the world's remaining forest area comprise edges $(<100 \mathrm{~m})$. The reduction of forest areas decreases the environmental heterogeneity and increases the area exposed to edge effects (Fahrig, 2003).

The forest edges composition may vary according to the type of matrix (Silva and Schmitt, 2015; Silva et al., 2017). The different responses are crucial because they can promote variability in forest edges and interiors. Edges can affect microclimate by modifying both the air and soil temperature, light availability, soil moisture and wind speed (Heithecker and Halpern, 2007; Marchand and Houle, 2006). Bergeron and Pellerin (2014) showed a strong species-area relationship that was influenced by surrounding land use, and conclude that fern richness decreased due increasing proportions of residential areas and urban heat islands in comparison to low urban influence.

According to Kupfer et al. (2006) the matrices' composition not only serve as a barrier, but also as a habitat within a landscape. In this sense, the natural matrices are recognized as being habitats more heterogeneous than anthropic matrices.

The Atlantic Forest is the second largest tropical rainforest in the American continent. In the past, it covered about 1.5 million $\mathrm{km}^{2}$ with $92 \%$ of this area in Brazil (Galindo-Leal and Câmara, 2003; Fundação SOS Mata Atlântica, 2017). Currently, only $8.5 \%$ of the remaining Atlantic forest area has more than 100 ha of the original forest indicating its degree of fragmentation (Fundação SOS Mata Atlântica, 2017). Among the phytophysiognomies of the Atlantic Forest, the Araucaria Forest is situated in the south and southeast of Brazil and characterized by the presence of Araucaria angustifolia (Bertol.) Kuntze, with subtropical climate and regular rainfall throughout the year. This phytophysiognomy is extremely fragmented, with a distribution area conditioned to $3 \%$ of its original surface (Fundação SOS Mata Atlântica, 2017).

Ferns and lycophytes are important indicators of environmental quality because they are sensitive to changes in abiotic factors (Ferrer-Castan and Vetaas, 2005; Silva et al., 2018; Silva and Schmitt, 2015), as demonstrated from environmental disturbances such as increased edge areas (Paciencia and Prado, 2004, 2005; Silva et al., 2011; Pereira et al., 2014; Silva and Schmitt, 2015). Thus, ferns and lycophytes can be an accurate tool to test the effects of fragmentation and loss of habitats, as well as the edge effects. Changes in abiotic factors, as humidity and shading conditions, may lead to the substitution of more sensitive by the species tolerant to the impacts caused by this process, resulting in the impoverishment and the decharacterization of the local native flora (Pereira et al., 2014).
The present study aims to compare the floristic composition between communities of ferns and lycophytes of the edge and interior in three fragments with different matrices, as well as to verify their phytosociological structure. The hypothesis of this study was: communities of ferns and lycophytes in fragments of forest with Araucaria suffer floristic and phytosociological simplification by the artificial edge effect when compared to natural matrices.

\section{Material and Methods}

\subsection{Study area}

The study was developed at the phytoecological unit denominated Araucaria Forest, Rio Grande do Sul, Brazil, whose characteristic elements are Araucaria angustifolia (Bertol.) Kuntze and natural fields (Teixeira and Moura Neto, 1986). According to the classification of Köppen-Geiger, the climate is type $\mathrm{Cfb}$ (Peel et al., 2007). The average annual temperature is $14.5^{\circ} \mathrm{C}$, and precipitation around $2.000 \mathrm{~mm}$ (according to the data obtained from the weather station Davis Vantage pro-2, installed near to study area). The soil is classified as humose aluminous cambisol (Streck et al., 2008).

\subsection{Data collection}

We selected three forest sites under influence of different types of vegetation in the matrix: (1) natural field site - NFS: $29^{\circ} 07^{\prime}$ 58'S and 50 06' 43”'W 1032 m a.s.1. (approx. 245ha); (2) Pinus plantation site PPS: $29^{\circ} 28^{\prime} 31^{\prime \prime S}$ and 50 20' 59"W $925 \mathrm{~m}$ a.s.1.; (3) cultivation of crops site - CCS: $29^{\circ} 28^{\prime} 44^{\prime \prime} S$ and $50^{\circ} 21^{\prime}$ 30 "W $906 \mathrm{~m}$ a.s.l. (both 2 and 3 share the same fragment, approx. 105ha). At each site, we draw two parallel transects of $500 \mathrm{~m}$ length. The first transect was at $5 \mathrm{~m}$ and the second transect at $100 \mathrm{~m}$ distance from a forest edge. Along each transect, we randomly selected 12 points, which were at least $10 \mathrm{~m}$ apart. It was established a total of 24 plots of $10 \times 10 \mathrm{~m}$. Therefore, we sampled a total of 72 plots ( 3 sites $\times 12$ replicates $x 2$ conditions: forest edge and interior).

In each plot, we recorded the composition and richness of terrestrial ferns and lycophytes. Species were identified using specialized bibliography, comparisons with herbarium vouchers and supporting specialists. We followed the taxonomic classification of families and genera of PPG I (2016). Fertile specimens were collected and deposited in the Herbarium Anchieta (PACA), at the Universidade do Vale do Rio dos Sinos, São Leopoldo, Rio Grande do Sul, Brazil.

The phytosociological parameters were based on the absolute and relative coverage data, as well as absolute and relative frequency to obtain the Importance Value - IV, an indicator of the most important species within the community which resulted from the means of the relative coverage and frequency of each species (adaptation by Mueller-Dombois and Ellenberg, 1974). The coverage was determined according to the scale proposed by Braun-Blanquet (1979). 


\subsection{Data analyses}

From a presence/absence matrix, we performed the Principal Coordinates Analysis (PCoA) to visualize the floristic dissimilarity among sampling sites using Euclidian similarity index. The floristic similarity between edge and interior sites was obtained using Sørensen-Dice index, providing a dendrogram from the UPGMA method, with ferns and lycophytes and another with ferns only. The analyses were performed using software Paleontological Statistics Package for Education and Data Analysis - PAST version 3.0 (Hammer et al., 2001)

\section{Results}

We recorded a total of 38 species in the studied areas, of which only two were lycophytes, distributed in 15 families.

NFS site: the edge of this site registered 11 species, the most important of this environment was Dicksonia sellowiana
(IV=39.03\%), followed by Macrothelypteris torresiana $(\mathrm{IV}=18.42 \%$ ) (Table 1). In the interior plots, 28 species were recorded and $D$. sellowiana was again the species with the highest importance value $(40.04 \%)$, followed by Dennstaedtia globulifera $(\mathrm{IV}=21.75 \%$ ) occurring in $83 \%$ and $100 \%$ of the plots (Table 2 ).

PPS site: in the edge, 14 species were inventoried. The most important species was Lastreopsis amplissima (VI=40.48 \%), followed by $D$. sellowiana $(\mathrm{VI}=23.36 \%)$ (Table 3) occurring in $100 \%$ and $75 \%$ of the plots respectively. In the interior site, 16 species were recorded. The same previous species were recorded with similar IV (42.33\% and $20.24 \%$, respectively), both occurring in $100 \%$ of the plots (Table 4 ).

CCS site: At the forest edge, 14 species and 12 genera were recorded. The most important species was L. amplissima $(\mathrm{VI}=58.39 \%)$, followed by $D$. sellowiana

Table 1. Interior of NFS.

\begin{tabular}{|c|c|c|c|c|c|c|c|}
\hline Family & Species & NP & AF\% & RF\% & $\mathrm{AC} \%$ & RC\% & IV\% \\
\hline Dicksoniaceae & Dicksonia sellowiana Hook & 10 & 83.3 & 12.9 & 307.3 & 67.0 & 40.0 \\
\hline Dennstaedtiaceae & Dennstaedtia globulifera (Poir.) Hieron. & 12 & 100.0 & 15.5 & 127.8 & 27.9 & 21.7 \\
\hline Dryopteridaceae & Ruhmora adiantiformis (G.Forst.) Ching & 6 & 50.0 & 7.7 & 1.9 & 0.4 & 4.1 \\
\hline Thelypteridaceae & $\begin{array}{l}\text { Amauropelta recumbens (Rosenst.) Salino \& } \\
\text { T.E.Almeida }\end{array}$ & 5 & 41.6 & 6.4 & 5.3 & 1.1 & 3.8 \\
\hline Hymenophyllaceae & $\begin{array}{l}\text { Crepidomanes pyxidiferum (L.) Dubuisson \& } \\
\text { Ebihara }\end{array}$ & 5 & 41.6 & 6.4 & 1.1 & 0.2 & 3.3 \\
\hline Dryopteridaceae & $\begin{array}{l}\text { Elaphoglossum sellowianum (Klotzsch ex } \\
\text { Kuhn) T. Moore }\end{array}$ & 4 & 33.3 & 5.1 & 0.4 & - & 2.6 \\
\hline Dennstaedtiaceae & Histiopteris incisa (Thunb.) J.Sm. & 3 & 25.0 & 3.9 & 5.0 & 1.0 & 2.5 \\
\hline Hymenophyllaceae & $\begin{array}{l}\text { Polyphlebium angustatum (Carmich.) Ebihara } \\
\text { \& Dubuisson }\end{array}$ & 3 & 25.0 & 3.9 & 0.7 & 0.1 & 2.0 \\
\hline Aspleniaceae & Asplenium gastonis Fée & 3 & 25.0 & 3.9 & - & - & 1.9 \\
\hline Thelypteridaceae & $\begin{array}{l}\text { Amauropelta stierii (Rosenst.) Salino \& } \\
\text { T.E.Almeida }\end{array}$ & 2 & 16.6 & 2.6 & 1.1 & 0.2 & 1.4 \\
\hline Athyriaceae & Deparia petersenii (Kunze) M.Kato & 2 & 16.6 & 2.6 & 0.9 & 0.2 & 1.4 \\
\hline Polypodiaceae & $\begin{array}{l}\text { Serpocaulon catharinae (Langsd. \& Fisch.) } \\
\text { A.R.Sm. }\end{array}$ & 2 & 16.6 & 2.6 & 0.3 & - & 1.3 \\
\hline Thelyoteridaceae & Amauropelta retusa (Sw.) Pic.Serm. & 2 & 16.6 & 2.6 & 0.2 & - & 1.3 \\
\hline Polypodiaceae & Pleopeltis hirsutissima (Raddi) de la Sota & 2 & 16.6 & 2.6 & 0.1 & - & 1.3 \\
\hline Hymenophyllaceae & Didymoglossum ovale E.Fourn. & 2 & 16.6 & 2.6 & - & - & 1.3 \\
\hline Polypodiaceae & Microgramma squamulosa (Kaulf.) de la Sota & 2 & 16.6 & 2.6 & - & - & 1.3 \\
\hline Cyatheaceae & Cyathea atrovirens (Langsd. \& Fisch.) Domin & 1 & 8.3 & 1.3 & 2.0 & 0.4 & 0.8 \\
\hline Selaginellaceae & Selaginella muscosa Spring & 1 & 8.3 & 1.3 & 2.0 & 0.4 & 0.8 \\
\hline Dryopteridaceae & Polysticum platylepis Fée & 1 & 8.3 & 1.3 & 1.1 & 0.2 & 0.7 \\
\hline Aspleniaceae & Asplenium serra Langsd. \& Fisch. & 1 & 8.3 & 1.3 & - & - & 0.6 \\
\hline Polypodiaceae & Pecluma pectinatiformis (Lindm.) M.G.Price & 1 & 8.3 & 1.3 & - & - & 0.6 \\
\hline Ophioglossaceae & Botrypus virginianus (L.) Michx. & 1 & 8.3 & 1.3 & - & - & 0.6 \\
\hline Blechnaceae & Blechnum austrobrasilianum de la Sota & 1 & 8.3 & 1.3 & - & - & 0.6 \\
\hline Pteridaceae & Vittaria lineata (L.) Sm. & 1 & 8.3 & 1.3 & - & - & 0.6 \\
\hline Polypodiaceae & Pecluma sicca (Lindm.) M.G.Price & 1 & 8.3 & 1.3 & - & - & 0.6 \\
\hline Aspleniaceae & Asplenium harpeodes Kunze & 1 & 8.3 & 1.3 & - & - & 0.6 \\
\hline Polypodiaceae & Pecluma recurvata (Kaulf.) M.G.Price & 1 & 8.3 & 1.3 & - & - & 0.6 \\
\hline Polypodiaceae & Pleopeltis pleopeltidis (Fée) de la Sota & 1 & 8.3 & 1.3 & - & - & 0.6 \\
\hline
\end{tabular}

Phytosociological parameters of fern and lycophyte species: $\mathrm{NP}=$ Number of plots that the specie occurred; $\mathrm{AF} \%=\mathrm{Absolute}$ Frequency; $\mathrm{RF} \%=$ Relative frequency; $\mathrm{AC} \%=$ Absolute Coverage $; \mathrm{RC} \%=$ relative coverage $; \mathrm{IV} \%=$ Importance value $;-=\leq 0.09$. 
Table 2. Edge of NFS.

\begin{tabular}{|c|c|c|c|c|c|c|c|}
\hline Family & Species & NP & $\mathbf{A F} \%$ & RF\% & $\mathrm{AC} \%$ & $\mathbf{R C} \%$ & IV\% \\
\hline Dicksoniaceae & Dicksonia sellowiana Hook & 4 & 33.3 & 13.3 & 34.4 & 64.7 & 39.0 \\
\hline Thelypteridaceae & Macrothelypteris torresiana (Gaudich.) Ching & 6 & 50.0 & 20.0 & 8.9 & 16.8 & 18.4 \\
\hline Thelypteridaceae & $\begin{array}{l}\text { Amauropelta recumbens (Rosenst.) Salino \& } \\
\text { T.E.Almeida }\end{array}$ & 3 & 25.0 & 10.0 & 3.7 & 7.0 & 8.5 \\
\hline Dryopteridaceae & Ruhmora adiantiformis (G.Forst.) Ching & 4 & 33.3 & 13.3 & 0.5 & 1.1 & 7.2 \\
\hline Polypodiaceae & Pleopeltis hirsutissima (Raddi) de la Sota & 4 & 33.3 & 13.3 & 0.1 & 0.2 & 6.7 \\
\hline Drypoteridaceae & Polystichum platylepis Fée & 2 & 16.6 & 6.6 & 3.6 & 6.8 & 6.7 \\
\hline Polypodiaceae & $\begin{array}{l}\text { Serpocaulon catharinae (Langsd. \& Fisch.) } \\
\text { A.R.Sm. }\end{array}$ & 3 & 25.0 & 10.0 & 0.1 & 0.3 & 5.1 \\
\hline Blechnaceae & $\begin{array}{l}\text { Lomaria spannagelii (Rosenst.) Gasper \& } \\
\text { V.A.O. Dittrich }\end{array}$ & 1 & 8.3 & 3.3 & 1.0 & 1.9 & 2.6 \\
\hline Blechnaceae & Blechnum austrobrasilianum de la Sota & 1 & 8.3 & 3.3 & 0.2 & 0.4 & 1.9 \\
\hline Athyriaceae & Deparia petersenii (Kunze) M.Kato & 1 & 8.3 & 3.3 & 0.2 & 0.4 & 1.8 \\
\hline Blechnaceae & Lomaridium plumieri (Desv.) C. Presl & 1 & 8.3 & 3.3 & - & - & 1.7 \\
\hline
\end{tabular}

Phytosociological parameters of fern species: $\mathrm{NP}=$ Number of plots with species presence; $\mathrm{AF} \%=$ Absolute Frequency; $\mathrm{RF} \%=$ Relative frequency; $\mathrm{AC} \%=$ Absolute Coverage; $\mathrm{RC} \%=$ relative coverage; $\mathrm{IV} \%=$ Importance value; $-=\leq 0.9$.

Table 3. Edge of PPS.

\begin{tabular}{|c|c|c|c|c|c|c|c|}
\hline Family & Species & NP & $\mathbf{A F} \%$ & $\mathbf{R F} \%$ & $\mathrm{AC} \%$ & $\mathrm{RC} \%$ & IV\% \\
\hline Dryopteridaceae & Lastreopsis amplissima (C.Presl) Tindale & 12 & 100.0 & 20.3 & 139.4 & 60.6 & 40.4 \\
\hline Dicksoniaceae & Dicksonia sellowiana Hook. & 9 & 75.0 & 15.2 & 72.3 & 31.4 & 23.3 \\
\hline Dryopteridaceae & Ruhmora adiantiformis (G.Forst.) Ching & 6 & 50.0 & 10.1 & 9.0 & 3.9 & 7.0 \\
\hline Aspleniaceae & Asplenium claussenii Hieron. & 6 & 50.0 & 10.1 & 0.2 & 0.1 & 5.1 \\
\hline Aspleniaceae & Asplenium harpeodes Kunze & 5 & 41.6 & 8.4 & 3.7 & 1.6 & 5.0 \\
\hline Cyatheaceae & $\begin{array}{l}\text { Cyathea atrovirens (Langsd. \& Fisch.) } \\
\text { Domin }\end{array}$ & 4 & 33.3 & 6.7 & 2.9 & 1.2 & 4.0 \\
\hline Dennstaedtiaceae & Dennstaedtia globulifera (Poir.) Hieron. & 4 & 33.3 & 6.7 & - & - & 3.4 \\
\hline Polypodiaceae & Pecluma recurvata (Kaulf.) M.G.Price & 3 & 25.0 & 5.0 & 0.5 & 0.2 & 2.6 \\
\hline Aspleniaceae & Asplenium maritianum C.Chr. & 2 & 16.6 & 3.3 & 0.6 & 0.3 & 1.8 \\
\hline Athyriaceae & Deparia petersenii (Kunze) M.Kato & 2 & 16.6 & 3.3 & 0.5 & 0.2 & 1.8 \\
\hline Polypodiaceae & Campyloneurum nitidum (Kaulf.) C.Presl & 2 & 16.6 & 3.3 & 0.3 & 0.1 & 1.7 \\
\hline Aspleniaceae & Asplenium gastonis Fée & 2 & 16.6 & 3.3 & - & - & 1.7 \\
\hline Blechnaceae & $\begin{array}{l}\text { Neoblechnum brasiliense (Desv.) Gasper \& } \\
\text { V.A.O. Dittrich }\end{array}$ & 1 & 8.3 & 1.6 & - & - & 0.8 \\
\hline Thelypteridaceae & Amauropelta retusa (Sw.) Pic.Serm. & 1 & 8.3 & 1.6 & - & - & 0.8 \\
\hline
\end{tabular}

Phytosociological parameters of fern species: NP = Number of plots with species presence; AF\% = Absolute Frequency; $\mathrm{RF} \%=$ Relative frequency; $\mathrm{AC} \%=$ Absolute Coverage; $\mathrm{RC} \%=$ relative coverage; IV\%: Importance value; $-=\leq 0.9$.

(VI=9.88\%) occurring in $100 \%$ and $75 \%$ of the plots respectively (Table 5). In the interior of the fragment 14 species and 12 genera were registered. The species that presented the highest VIs were L. amplissima (56.39\%), Selaginella muscosa (10.70\%.) and Lomaridium plumieri, occurring in $100 \%, 67 \%$ and $58 \%$ of the plots respectively (Table 6). In both environments, the richness was 13 families.

The forest edge and interior in PPS and CCS sites showed high index of similarity ( $<70 \%$, Figure $1 \mathrm{~A})$. Differently, NFS site had a similarity about $35 \%$ between forest edge and interior (Figure 1A). In the dendrogram formed by ferns only (Figure 1B), it indicates that, the exclusion of the group of the lycophytes further accentuates the differences mainly between the NFS site with respect to the other sites.
The PCoA separated the plots from NFS site on edge and interior showing that the species composition between the areas is quite heterogeneous due to the sharing of only eight species of the 31 species found for this site. The proximity and overlapping of some interior plots revealed a greater floristic homogeneity in the area, while the dispersion of the edge plots demonstrates a greater dissimilarity (Figure 2A). For the PPS site, the differentiation of the plots between the environments of edge and interior was less evident (Figure 2B). The separation of the plots between edge and interior of the CCS site was even less evident than at the previous site demonstrating greater floristic homogeneity among the environment. In comparison among the edge plots, high dispersion occurred indicating 
Table 4. Interior of PPS.

\begin{tabular}{|c|c|c|c|c|c|c|c|}
\hline Family & Species & NP & $\mathbf{A F} \%$ & RF\% & $\mathrm{AC} \%$ & $\mathrm{RC} \%$ & IV\% \\
\hline Dryopteridaceae & Lastreopsis amplissima (C.Presl) Tindale & 12 & 100.0 & 17.6 & 427.0 & 67.0 & 42.3 \\
\hline Dicksoniaceae & Dicksonia sellowiana Hook & 12 & 100.0 & 17.6 & 146.7 & 23.0 & 20.3 \\
\hline Blechnaceae & Lomaridium plumieri (Desv.) C. Presl & 8 & 66.6 & 11.7 & 44.5 & 7.0 & 9.3 \\
\hline Thelypteridaceae & Amauropelta retusa (Sw.) Pic.Serm. & 10 & 83.3 & 14.7 & 7.3 & 1.1 & 7.9 \\
\hline Dennstaedtiaceae & Dennstaedtia globulifera (Poir.) Hieron & 6 & 50.0 & 8.8 & 1.6 & 0.2 & 4.5 \\
\hline Aspleniaceae & Asplenium maritianum C.Chr & 5 & 41.6 & 7.3 & 1.9 & 0.3 & 3.8 \\
\hline Aspleniaceae & Asplenium harpeodes Kunze & 3 & 25.0 & 4.4 & 3.0 & 0.4 & 2.4 \\
\hline Aspleniaceae & Asplenium claussenii Hieron. & 2 & 16.6 & 2.9 & 1.4 & 0.2 & 1.5 \\
\hline Dryopteridaceae & Ruhmora adiantiformis (G.Forst.) Ching & 2 & 16.6 & 2.9 & 0.5 & - & 1.5 \\
\hline Athyriaceae & Deparia petersenii (Kunze) M.Kato & 2 & 16.6 & 2.9 & 0.2 & - & 1.4 \\
\hline Cyatheaceae & Cyathea atrovirens (Langsd. \& Fisch.) Domin & 1 & 8.3 & 1.4 & 1.0 & 0.1 & 0.8 \\
\hline Dryopteridaceae & Polystichum platylepis Fée & 1 & 8.3 & 1.4 & 1.0 & 0.1 & 0.8 \\
\hline Thelypteridaceae & $\begin{array}{l}\text { Amauropelta stierii (Rosenst.) Salino \& } \\
\text { T.E.Almeida }\end{array}$ & 1 & 8.3 & 1.4 & 0.5 & - & 0.7 \\
\hline Polypodiaceae & Microgramma squamulosa (Kaulf.) de la Sota & 1 & 8.3 & 1.4 & - & - & 0.7 \\
\hline Selaginellaceae & Selaginella muscosa Spring & 1 & 8.3 & 1.4 & - & - & 0.7 \\
\hline Thelypteridaceae & $\begin{array}{l}\text { Amauropelta recumbens (Rosenst.) Salino \& } \\
\text { T.E.Almeida }\end{array}$ & 1 & 8.3 & 1.4 & - & - & 0.7 \\
\hline
\end{tabular}

Phytosociological parameters of fern and lycophyte species: $\mathrm{NP}=$ Number of plots with species presence; $\mathrm{AF} \%=\mathrm{Absolute}$ Frequency; $\mathrm{RF} \%=$ Relative frequency; $\mathrm{AC} \%=$ Absolute Coverage $; \mathrm{RC} \%=$ relative coverage; $\mathrm{IV} \%=$ Importance value; $-=\leq 0.09$.

Table 5. Edge of CCS.

\begin{tabular}{|c|c|c|c|c|c|c|c|}
\hline Family & Species & NP & $\mathbf{A F} \%$ & RF\% & $\mathrm{AC} \%$ & $\mathrm{RC} \%$ & IV\% \\
\hline Dryopteridaceae & Lastreopsis amplissima (C.Presl) Tindale & 12 & 100.0 & 24.0 & 985 & 92.7 & 58.3 \\
\hline Dicksoniaceae & Dicksonia sellowiana Hook & 9 & 75.0 & 18.0 & 18.6 & 1.7 & 9.8 \\
\hline Blechnaceae & Lomaridium plumieri (Desv.) C. Presl & 5 & 41.6 & 10.0 & 3.0 & 0.2 & 5.1 \\
\hline Selaginellaceae & Selaginella muscosa Spring & 4 & 33.3 & 8.0 & 11.4 & 1.0 & 4.5 \\
\hline Aspleniaceae & Asplenium maritianum C.Chr & 4 & 33.3 & 8.0 & 0.2 & - & 4.0 \\
\hline Dryopteridaceae & $\begin{array}{l}\text { Elaphoglossum sellowianum (Klotzsch ex } \\
\text { Kuhn) T. Moore }\end{array}$ & 4 & 33.3 & 8.0 & 0.1 & - & 4.0 \\
\hline Dryopteridaceae & Ruhmora adiantiformis (G.Forst.) Ching & 3 & 25.0 & 6.0 & 14 & 1.3 & 3.6 \\
\hline Lycopodiaceae & Diphasiastrum thyoides (Willd) Holub & 1 & 8.3 & 2.0 & 28.7 & 2.7 & 2.3 \\
\hline Thelypteridaceae & Amauropelta retusa (Sw.) Pic.Serm. & 2 & 16.6 & 4.0 & 0.1 & - & 2.0 \\
\hline Thelypteridaceae & $\begin{array}{l}\text { Amauropelta recumbens (Rosenst.) Salino \& } \\
\text { T.E.Almeida }\end{array}$ & 2 & 16.6 & 4.0 & - & - & 2.0 \\
\hline Dennstaedtiaceae & Dennstaedtia globulifera (Poir.) Hieron & 1 & 8.3 & 2.0 & - & - & 1.0 \\
\hline Hymenophyllaceae & $\begin{array}{l}\text { Polyphlebium angustatum (Carmich.) } \\
\text { Ebihara \& Dubuisson }\end{array}$ & 1 & 8.3 & 2.0 & - & - & 1.0 \\
\hline Polypodiaceae & Pecluma recurvata (Kaulf.) M.G.Price & 1 & 8.3 & 2.0 & - & - & 1.0 \\
\hline Polypodiaceae & Pecluma sicca (Lindm.) M.G.Price & 1 & 8.3 & 2.0 & - & - & 1.0 \\
\hline
\end{tabular}

greater dissimilarity between them. This result can also be reported in the interior plots (Figure 2C).

\section{Discussion}

The results showed distinct intensities of the edge effect under analyzed sites, considering the phytosociological aspects of ferns and lycophytes as a parameter. According to Laurance and Bierregaard (1997), the matrix composition can influence the edge effects because of the differences in physical and biotic changes of the fragments. The greatest richness found in the interior of the NFS site and it was twice the number of species found in the interiors of the other sites analyzed indicating that areas surrounded by matrices of natural vegetation in forest with Araucaria phytophysiognomy present greater richness than areas surrounded by non-original matrices, indicating that the edge effect is attenuated in the natural environment. Bergeron and Pellerin (2014) demonstrated a decrease in fern species richness influenced by an anthropized matrix.

From the phytosociological data, it was verified that 18 species occurred in only one or two plots from the 
Table 6. Interior of CCS.

\begin{tabular}{|c|c|c|c|c|c|c|c|}
\hline Family & Species & NP & $\mathbf{A F} \%$ & $\mathbf{R F} \%$ & $\mathrm{AC} \%$ & $\mathbf{R C} \%$ & IV\% \\
\hline Dryopteridaceae & Lastreopsis amplissima (C.Presl) Tindale & 12 & 100.0 & 24.4 & 710 & 88.2 & 56.3 \\
\hline Selaginellaceae & Selaginella muscosa Spring & 8 & 66.6 & 16.3 & 40.8 & 5.0 & 10.7 \\
\hline Blechnaceae & Lomaridium plumieri (Desv.) C. Presl & 7 & 58.3 & 14.2 & 7.8 & 0.9 & 7.6 \\
\hline Thelypteridaceae & $\begin{array}{l}\text { Amauropelta recumbens (Rosenst.) Salino \& } \\
\text { T.E.Almeida }\end{array}$ & 5 & 41.6 & 10.2 & 2.9 & 0.3 & 5.2 \\
\hline Thelypteridaceae & Amauropelta retusa (Sw.) Pic.Serm. & 5 & 41.6 & 10.2 & 2.3 & 0.2 & 5.2 \\
\hline Dicksoniaceae & Dicksonia sellowiana Hook & 4 & 33.3 & 8.1 & 10.7 & 1.3 & 4.7 \\
\hline Osmundaceae & Osmunda regalis $\mathrm{L}$. & 1 & 8.3 & 2.0 & 13 & 1.6 & 1.8 \\
\hline Dryopteridaceae & $\begin{array}{l}\text { Elaphoglossum sellowianum (Klotzsch ex } \\
\text { Kuhn) T. Moore }\end{array}$ & 1 & 8.3 & 2.0 & 6 & 0.7 & 1.3 \\
\hline Dryopteridaceae & Ruhmora adiantiformis (G.Forst.) Ching & 1 & 8.3 & 2.0 & 5.2 & 0.6 & 1.3 \\
\hline Aspleniaceae & Asplenium serra Langsd. \& Fisch a & 1 & 8.3 & 2.0 & 4 & 0.5 & 1.2 \\
\hline Polypodiaceae & Pecluma recurvata (Kaulf.) M.G.Price & 1 & 8.3 & 2.0 & 1 & 0.1 & 1.0 \\
\hline Dennstaedtiaceae & Dennstaedtia globulifera (Poir.) Hieron & 1 & 8.3 & 2.0 & 0.2 & - & 1.0 \\
\hline Cyatheaceae & Cyathea atrovirens (Langsd. \& Fisch.) Domin & 1 & 8.3 & 2.0 & - & - & 1.0 \\
\hline Athyriaceae & Deparia petersenii (Kunze) M.Kato & 1 & 8.3 & 2.0 & - & - & 1.0 \\
\hline
\end{tabular}

Phytosociological parameters of fern and lycophyte species: $\mathrm{NP}=$ Number of plots that the specie occurred; $\mathrm{AF} \%=\mathrm{Absolute}$ Frequency; $\mathrm{RF} \%=$ Relative frequency; $\mathrm{AC} \%=$ Absolute Coverage $; \mathrm{RC} \%=$ relative coverage; $\mathrm{IV} \%=$ Importance value; $-=\leq 0.09$.

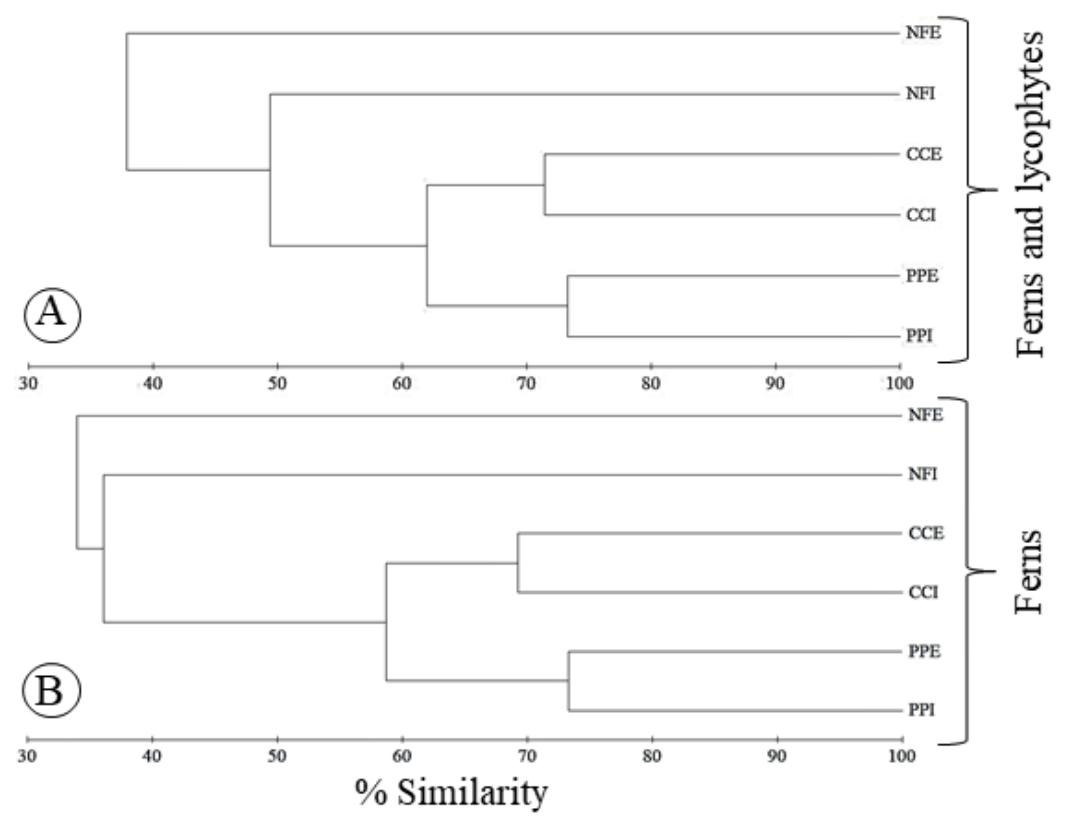

Figure 1. Dendrogram of floristic similarity generated by the UPGMA method using the Sorensen-Dice coefficient. $\mathrm{NFE}=$ edge of natural field site; NFI = interior of natural field site; CCE = edge of cultivation of crops site; $\mathrm{CCI}=$ interior of cultivation of crops site; PPE = edge of pine plantation site; PPI = interior of pine plantation site. (A) Dendrogram with Ferns and lycophytes; (B) Dendrogram with ferns only.

interior of the NFS site. In the other edges and interiors investigated, the richness never reached more than half (9) of that value. This finding indicates that the ferns and lycophytes community of NFS interior site has a less homogenous distribution when compared to other environments and presents a larger number of rare and less abundant species. According to Nee et al. (1991), rich assemblages are characterized by rare species. The presence of a few lycophytes was expected, since the terrestrial species of this group in the Araucaria Forest are less frequent compared to the ferns (JBRJ, 2017).

Hymenophyllaceae occurred mainly in the interior of NFS. A study developed by Paciencia and Prado (2005) indicated a prevalence of species of this family in 


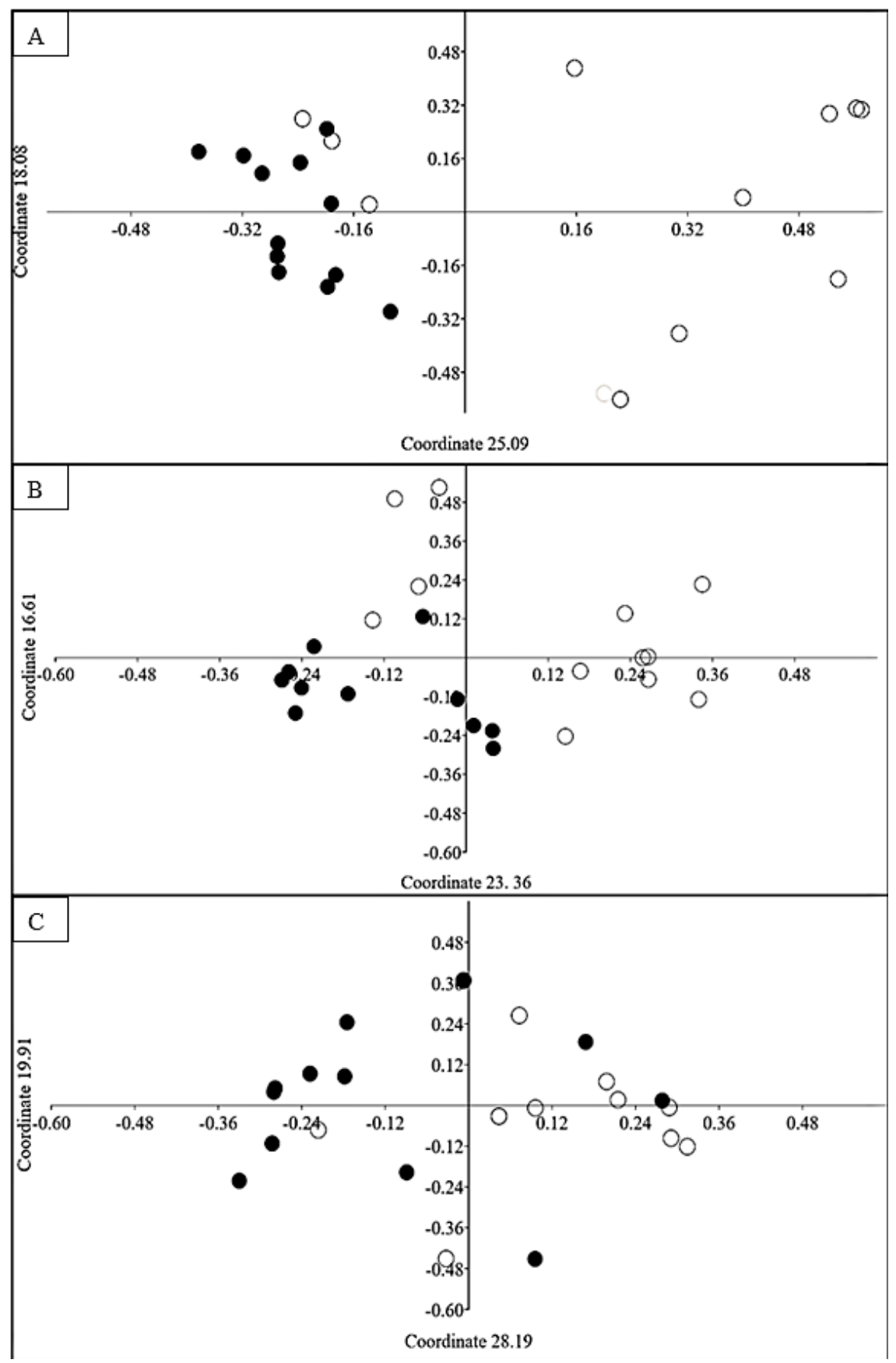

Figure 2. Principal coordinates analysis (PCoA) of sampled plots at the edge and in the interior of the NFS (A), PPS (B) and CCS (C) sites. Edge (०), Interior $(\bullet)$.

forest interior. Hymenophyllaceae have leaves with low saturation point, supporting high humidity levels and low luminosity (Benzing, 1987; Dubuisson et al., 2009; Windisch, 2015). On the other hand, the low saturation point renders them more susceptible to desiccation and high photosynthetically active radiation, which eventually becomes a limiting point to its occurrence in other sites. Another family that deserves attention and found inside of the NFS was Ophyoglossaceae, with the representative specie Bothypus virginianus, this fern is rarely found in Rio Grande do Sul (Lorscheitter et al., 1998) it is also on the red list of endangered species of Rio Grande do Sul, in the vulnerable category (Rio Grande do Sul, 2014), reinforcing the importance of this interior environment in keeping species with restricted distribution in the south of Brazil.

Nearly half of fern species habitually epiphytic occurred in the understory of the NFS interior site should be the result of the greater environmental heterogeneity in this 
site. According to Magurran (2004) different conditions and resources availability in natural environments favors a greater variety of habitats, reflecting the level of conservation of the place. Therefore, the ecosystem can support different species with different functional characteristics provide an increase in richness. In a natural environment matrix, the anthropic pressures are less impactful, which can contribute to the heterogeneity and the development of some epiphytic ferns in the understory of this interior site.

The forests edge in PPS site presented high floristic similarity when compared with their interior, the same can be applied to the CCS site indicating that environments surrounded by non-original matrices may cause a more pronounced edge effect than natural matrices and the edge effect reaches depths greater than $100 \mathrm{~m}$. According to Brummitt et al. (2016), agriculture or monoculture matrices impact about $80 \%$ of the ferns considered endangered in the world. These results indicate that edge effect in ferns may be more intense in sites inserted in fragments that present this type of surrounding matrix. The fragmentation tends to simplify ecosystems and decrease heterogeneity (Fahrig, 2003; Williams, 1964).

Lastreopsis amplissima was the species with the highest importance value in PPS and CCS (edge and interior), Blume et al. (2010) showed that this species presented the highest values of abundance among the ferns recorded in a forest fragment with araucaria, surrounded by a strongly anthropized matrix (Pine plantations urban influence) indicating that these species can be resilient to environments with impacted matrices such as those presented in this study.

In the case of Dicksonia sellowiana, the high IV suggests a high ecological amplitude, independent of the surround matrix (NFS; PPS) and habitat (edge or interior). Although this tree fern obtained high IV in PPS, this species presented values two to four times greater in the NFS both in the edge and in the interior, suggesting that this species has its distribution potential and reproductive success favored in a natural environment matrix when compared to artificial ones.

This species provides habitat to the establishment of epiphytes and hemiepiphytes (Becker et al., 2015; Negrão et al., 2017), moreover it also provides a great amount of organic matter to the soil (Fraga et al., 2008).

In the unnatural matrices sites, the presence of these two species together indicated percentages of IV always higher than $60 \%$ in both edges and interiors. As a result, it can be inferred that these two ferns are resilient to artificial edges with anthropized environment matrices (PPS and CCS). Silva and Schmitt (2015) also verified this effect in ferns and showed that changes caused by forest edges eliminate species that are less tolerant to environmental change favoring the success of others that are adapted. Artificial edges can eliminate sensitive species but also be responsible for the addition of species tolerant to climatic conditions of the altered environment (Laurance et al., 1998).

Araucaria Forests and their surrounding natural fields have suffered direct anthropic pressures caused mainly by the transformation of their areas into pastures and agricultural land, commercial tree plantations and burning practices (Bittencourt and Sebbenn, 2007; Silva and Schmitt, 2015; Bilenca and Miñarro, 2004). This study verified that in spite of a decrease in the richness of the edge in the site connected to natural field, the interior of the same site presented high richness and in comparison to the other environments, it presented the best conditions for the development of ferns. The results demonstrated that the site with natural fields matrix was less affected by edge effects than forests with surrounding anthropized matrix. Based on these results, we conclude that fern conservation efforts should focus on fragments inserted in natural field because of the conversion of natural grassland into Pinus and farming fields leads to the loss of fern and lycophytes species both on the edge and in the forest interiors.

\section{Acknowledgements}

This work was supported by the Coordenação de Aperfeiçoamento de Pessoal de Nível Superior (CAPES) [scholarship no. 88887.146950/2017-00 awarded to VLS], Universidade Feevale [JLS is supported by CNPq proj. no. 308926/2017-0], and the Instituto de Ecología, A.C. [proj. no. 20030-10796 to KM]. We thank to biology students, Renan Kauê Port and Fernando Bertoldi de Oliveira for their assistance during fieldwork.

\section{References}

BECKER, D.F.P., MÜLLER, A. and SCHMITT, J.L., 2015. Influência dos forófitos Dicksonia sellowiana e Araucaria angustifolia sobre a comunidade de epífitos vasculares em Floresta com Araucária. Floresta, vol. 45, no. 4, pp. 781-790. http://dx.doi. org/10.5380/rf.v45i4.37082.

BENZING, D.H., 1987. Vascular epiphytism: taxonomic participation and adaptative diversity. Annals of the Missouri Botanical Garden, vol. 74, no. 2, pp. 183-204. http://dx.doi. org/10.2307/2399394.

BERGERON, A. and PELlERIN, S., 2014. Pteridophytes as indicators of urban forest integrity. Ecological Indicators, vol. 38, pp. 40-49. http://dx.doi.org/10.1016/j.ecolind.2013.10.015.

BILENCA, D.N. and MIÑARRO, F.O., 2004. Identificación de Áreas Valiosas de Pastizal (AVPs) en las Pampas y Campos de Argentina, Uruguay y sur de Brasil. Buenos Aires: Fundación Vida Silvestre, vol. 1.

BITTENCOURT, J.V.M. and SEBBENN, A.M., 2007. Patterns of pollen and seed dispersal in a small, fragmented population of the wind pollinated tree Araucaria angustifolia in southern Brazil. Heredity, vol. 99, no. 6, pp. 580-591. http://dx.doi.org/10.1038/ sj.hdy.6801019. PMid:17928810.

BLUME, M., RECHENMACHER, C. and SCHMITT, J.L., 2010. Padrão de distribuição espacial de samambaias no interior florestal do Parque Natural Municipal da Ronda, Rio Grande do Sul, Brasil. Pesquisas Botânica, vol. 61, pp. 219-227.

BRAUN-BLANQUET, J., 1979. Fitosociología: bases para el estudio de las comunidades 435 vegetales. Madrid: H. Blume. 
BRUMMITT, N., ALETRARI, E., SYFERT, M.M. and MULLIGAN, M., 2016. Where are threatened ferns found? Global conservation priorities for pteridophytes. Journal of Systematics and Evolution, vol. 54, no. 6, pp. 604-616. http:// dx.doi.org/10.1111/jse.12224.

DUBUISSON, J., SCHNEIDER, H. and HENNEQUIN, S., 2009. Epiphytism in ferns: diversity and history. Comptes Rendus Biologies, vol. 332, no. 2-3, pp. 120-128. http://dx.doi. org/10.1016/j.crvi.2008.08.018. PMid:19281945.

FAHRIG, L., 2003. Effects of habitat fragmentation on biodiversity. Annual Review of Ecology Evolution and Systematics, vol. 34, no. 1, pp. 487-515. http://dx.doi.org/10.1146/annurev. ecolsys.34.011802.132419.

FERRER-CASTÁN, D. and VETAAS, O.R., 2005. Pteridophyte richness climate and topography in the Iberian Peninsula: comparing spatial and nonspatial models of richness patterns. Global Ecology and Biogeography, vol. 14, no. 2, pp. 155-165. http://dx.doi.org/10.1111/j.1466-822X.2004.00140.x.

FRAGA, L.L., SILVA, L.B. and SCHMITT, J.L., 2008. Composition and vertical distribution of epiphytic pteridophytes on Dicksonia sellowianaHook. (Dicksoniaceae), in mixed ombrophylous forest in Southern Brazil. Biota Neotropica, vol. 8, no. 4, pp. 123-129. http://dx.doi.org/10.1590/S1676-06032008000400011.

FUNDAÇÃO SOS MATA ATLÂNTICA, 2017 [viewed 21 November 2017]. Atlas dos remanescentes florestais da Mata Atlântica: periodo 2015-2016 [online]. São Paulo: Fundação SOS Mata Atlântica, 69 p. Available from: https://www.sosma.org.br/ link/Atlas_Mata_Atlantica_2015-2016_relatorio_tecnico_2017.pdf

GALINDO-LEAL, C. and CÂMARA, I.G., 2003. Atlantic forest hotspots status: an overview. In: C. GALINDO-LEAL and I. G. CÂMARA, eds. The Atlantic Forest of South America: biodiversity status, threats, and outlook. Washington: Center for Applied Biodiversity Science e Island Press, pp. 3-11.

HADDAD, N.M., BRUDVIG, L.A., CLOBERT, J., DAVIES, K.F., GONZALEZ, A., HOLT, R.D., LOVEJOY, T.E., SEXTON, J.O., AUSTIN, M.P., COLLINS, C.D., COOK, W.M., DAMSCHEN, E.I., EWERS, R.M., FOSTER, B.L., JENKINS, C.N., KING, A.J., LAURANCE, W.F., LEVEY, D.J., MARGULES, C.R., MELBOURNE, B.A., NICHOLLS, A.O., ORROCK, J.L., SONG, D.X. and TOWNSHEND, J.R., 2015. Habitat fragmentation and its lasting impact on Earth's ecosystems. Science Advances, vol. 1, no. 2, pp. e1500052. http://dx.doi.org/10.1126/sciadv.1500052. PMid:26601154.

HAMMER, Ø., HARPER, D.A.T. and RYAN, P.D., 2001. Paleontological statistics package for education and data analysis. Palaeontologia Electronica, vol. 4, pp. 1-9.

HARPER, K.A., MACDONALD, S.E., BURTON, P.J., CHEN, J., BROSOFSKE, K.D., SAUNDERS, S.C., EUSKIRCHEN, E.S., ROBERTS, D., JAITEH, M.S. and ESSEEN, P.-A., 2005. Edge influence on forest structure and composition in fragmented landscapes. Conservation Biology, vol. 19, no. 3, pp. 768-782. http://dx.doi.org/10.1111/j.1523-1739.2005.00045.x.

HEITHECKER, T.D. and HALPERN, C.B., 2007. Edge-related gradients in microclimate in forest aggregates following structural retention harvests in western Washington. Forest Ecology and Management, vol. 248, no. 3, pp. 163-173. http://dx.doi. org/10.1016/j.foreco.2007.05.003.

JARDIM BOTÂNICO DO RIO DE JANEIRO - JBRJ, 2017 [viewed 21 November 2017]. Flora do Brasil 2020 [online]. Rio de Janeiro: JBRJ. Available from: http://floradobrasil.jbrj.gov.br/
KUPFER, J.A., MALANSON, G.P. and FRANKLIN, S.B., 2006. Not seeing the ocean for the islands: the mediating influence of matrix-based processes on forest fragmentation effects. Global Ecology and Biogeography, vol. 15, no. 1, pp. 8-20. http://dx.doi. org/10.1111/j.1466-822X.2006.00204.x.

LAURANCE, W.F. and BIERREGAARD, R.O., 1997. Tropical forest remnants: ecology, management and conservation of fragmented communities. Chicago: University of Chicago Press, $632 \mathrm{p}$.

LAURANCE, W.F., FERREIRA, L.V., MERONA, J.M.R.-D., LAURANCE, S.G., HUTCHINGS, R.W. and LOVEJOY, T.E., 1998. Effects of forest fragmentation on recruitment patterns in Amazonian tree communities. Conservation Biology, vol. 12, no. 2 , pp. 460-464. http://dx.doi.org/10.1046/j.1523-1739.1998.97175.x.

LORSCHEITTER, M.L., ASHRAF, A.R., BUENO, R.M. and MOSBRUGGER, V., 1998. Pteridophyte spores of Rio Grande do Sul flora, Brazil. Part I. Palaeontographica Abteilung B. Palaöphytologie, vol. 246, pp. 1-113

MAGURRAN, A.E., 2004. Measuring biological diversity. Oxford: Blackwell Science, $256 \mathrm{p}$.

MARCHAND, P. and HOULE, G., 2006. Spatial patterns of plant species richness along a forest edge: what are their determinants? Forest Ecology and Management, vol. 223, no. 1-3, pp. 113-124. http://dx.doi.org/10.1016/j.foreco.2005.10.064.

MUELLER-DOMBOIS, D. and ELLENBERG, H., 1974. Aims and methods of vegetation ecology. New York: Jonh Wiley, $24 \mathrm{p}$.

NEE, S., HARVEY, P.H. and MAY, R.M., 1991. Lifting the veil on abundance patterns. Proceedings. Biological Sciences, vol. 243, no. 1307, pp. 161-163. http://dx.doi.org/10.1098/rspb.1991.0026.

NEGRÃO, R., SAMPAIO-E-SILVA, T., KORTZ, A.R., MAGURRAN, A. and SILVA MATOS, D.M., 2017. An endangered tree fern increases beta-diversity at a fine scale in the Atlantic Forest Ecosystem. Flora, vol. 234, pp. 1-6. http:// dx.doi.org/10.1016/j.flora.2017.05.020.

PACIENCIA, M.L.B. and PRADO, J., 2004. Efeitos de borda sobre a comunidade de pteridófitas na Mata Atlântica da região de Una, sul da Bahia, Brasil. Revista Brasileira de Botanica. Brazilian Journal of Botany, vol. 27, no. 4, pp. 641-653. http:// dx.doi.org/10.1590/S0100-84042004000400005.

PACIENCIA, M.L.B. and PRADO, J., 2005. Effects of forest fragmentation on pteridophyte diversity in a tropical rain forest in Brazil. Plant Ecology, vol. 180, no. 1, pp. 87-104. http://dx.doi. org/10.1007/s11258-005-3025-x.

PEEL, M.C., FINLAYSON, B.L. and MCMAHON, T.A., 2007. Updated world map of the Köppen-Geiger climate classification. Hydrology and Earth System Sciences Discussions, vol. 11, no. 5, pp. 1633-1644. http://dx.doi.org/10.5194/hess-11-1633-2007.

PEREIRA, A.F.N., SILVA, I.A.A., SANTIAGO, A.C.P. and BARROS, I.C.L., 2014. Efeito de borda sobre a comunidade de samambaias em fragmento de Floresta Atlântica (Bonito, Pernambuco, Brasil). Interciencia, vol. 39, no. 4, pp. 281-287.

PTERIDOPHYTE PHYLOGENY GROUP - PPG I, 2016. A community-derived classification for extant lycophytes and ferns. Journal of Systematics and Evolution, vol. 54, no. 6, pp. 563-603. http://dx.doi.org/10.1111/jse.12229.

RIO GRANDE DO SUL, 2014. Decreto Estadual $n^{\circ}$ 52.109, de 1 de dezembro de 2014. Declara as espécies da flora nativa 
ameaçadas de extinção do Estado do Rio Grande do Sul. Diário Oficial do Estado, Porto Alegre, 2 dez. no. 223, pp. 2-11.

SILVA, I.A.A., PEREIRA, A.F.N. and BARROS, I.C.L., 2011. Edge effects on fern community in an Atlantic Forest remnant of Rio Formoso, PE, Brazil. Brazilian Journal of Biology $=$ Revista Brasileira de Biologia, vol. 71, no. 2, pp. 421-430. http://dx.doi. org/10.1590/S1519-69842011000300011. PMid:21755159.

SILVA, V.L. and SCHMITT, J.L., 2015. The effects of fragmentation on Araucaria Forest: analysis of the fern and lycophyte communities at sites subject to different edge conditions. Acta Botanica Brasílica, vol. 29, no. 2, pp. 223-230. http://dx.doi. org/10.1590/0102-33062014abb3760.

SILVA, V.L., MEHLTRETER, K.V. and SCHMITT, J.L., 2018. Ferns as potential ecological indicators of edge effects in two types of Mexican forests. Ecological Indicators, vol. 93, pp. 669-676. http://dx.doi.org/10.1016/j.ecolind.2018.05.029.

SILVA, V.L., MALLMANN, I.T., CUNHA, S. and SCHMITT, J.L., 2017. Impacto do efeito de borda sobre a comunidade de samambaias epifíticas em Floresta com Araucária. Revista Brasileira de Ciências Ambientais, vol. 45, no. 45, pp. 19-32. http://dx.doi.org/10.5327/Z2176-947820170229.

STRECK, E.V., KÄMPF, N., DALMOLIN, R.S.D., KLAMT, E., NASCIMENTO, P.C., GIASSON, E. and PINTO, L.F.S., 2008. Solos do Rio Grande do Sul. 2. ed. Porto Alegre: EMATERRS, $222 \mathrm{p}$.

TEIXEIRA, M.B. and MOURA NETO, N.A.B.C., 1986. As regiões fitoecológicas, sua natureza e seus recursos econômicos: estudo fitogeográfico. Rio de Janeiro: Projeto RADAMBRASIL.

WILLIAMS, C.B., 1964. Patterns in the balance of nature and related problems in quantitative ecology. London: Academic Press, $324 \mathrm{p}$.

WINDISCH, P.G., 2015. Hymenophyllaceae (Polypodiopsida) no Estado do Rio Grande do Sul. Pesquisas: Botânica, vol. 65, pp. 15-48. 